\title{
Secondary Hyperparathyroidism in Osteomalacia
}

\author{
N. C. THALASSINOS, ${ }^{*}$ M.D. ; SUSAN WICHT, † B.Sc. ; G. F. JOPLIN, $\ddagger$ PH.D., M.R.C.P.
}

\begin{abstract}
Cummary: Twenty-one patients with histologically $\checkmark$ proved osteomalacia from various causes were investigated for biochemical and radiological evidence of osteomalacia and secondary hyperparathyroidism. Among the 15 who maintained a normal serum calcium, seven had a raised phosphate excretion index, seven had a raised serum alkaline phosphatase, and six had phalangeal erosions. On the other hand, six patients had a subnormal serum calcium; of these, none showed a raised phosphate excretion index, one had a raised serum alkaline phosphatase, and one had erosions. The phosphate excretion index and the alkaline phosphatase were strongly correlated $(r=+0.84)$. It is concluded that this absence of manifest secondary hyperparathyroidism in some patients with osteomalacia is due to failure of an increase in the release of parathyroid hormone. Measurement of phosphaturia does not appear to be a useful means of detecting osteomalacia. Subsequently, the 24-hour (stable) strontium space measurement was found to be the most sensitive single biochemical screening test for osteomalacia.
\end{abstract}

\section{Introduction}

The existence of parathyroid hyperplasia in osteomalacia was described as early as 1907 by Erdheim (cited by Fourman and Royer, 1968), who found enlargement or hyperplasia of the parathyroids at necropsy on eight patients with osteomalacia, and interpreted the changes as compensatory. Bartos and Henneman (1965) reported that all but one of 17 patients with osteomalacia had an increase in the weight of the glands and/or microscopical evidence of hyperplasia.

Albright and Reifenstein (1948), however, recognized that there are some patients with osteomalacia in whom the serum alkaline phosphatase is normal even though the calcium $\times$ phosphate product is low, thus suggesting that manifest secondary hyperparathyroidism may not be an invariable occurrence. Among their series of 85 patients with sprue, Salvesen and Böe (1953) found 12 who had low serum calcium and/or tetany, but radiographs of the bones were normal. Among a series of 36 infants with radiological features of rickets Taitz and de Lacy (1962) found nine with hypocalcaemic tetany yet a relatively low phosphorus clearance. Fourman and Haapanen (1964) further investigated this apparent failure of secondary hyperparathyroidism; they described four cases of osteomalacia in which there was hypocalcaemia yet no phalangeal erosions; none of these showed any response to exogenous parathyroid hormone. Similarly, Evanson (1966) described the cases of hypocalcaemic patients with steatorrhoea in whom parathyroid extract did not raise the serum calcium. Fraser et al. (1967), in recording 39 infants with vitamin-D deficiency, divided the evolution of the disease into stages, in the first of which hypocalcaemia was the only biochemical finding and at this stage convulsions were common; subsequently the signs of secondary hyperparathyroidism with normocalcaemia developed.

\footnotetext{
* Research Fellow and Honorary Registrar.

+ Research Assistant.

$¥$ Lecturer and Consultant Physician in Clinical Endocrinology. Endocrine Unit, Royal Postgraduate Medical School, Hammersmith Hospital, London W.12.
}

On present-day concepts secondary hyperparathyroidism is apt to occur whenever there is a tendency for the serum calcium to fall, as in vitamin-D deficiency (Au and Raisz, 1965), and such patients may then present with any of the consequences of increased parathyroid hormone secretion, such as radiological and histological bone changes, raised serum alkaline phosphatase, and increased phosphaturia; the end-result of this process opposes the fall in serum calcium.

One would therefore expect evidence of secondary hyperparathyroidism to be universally present in vitamin-D-deficiency osteomalacia, its absence requiring an explanation; it could be either a defective capacity for increase in activity of the parathyroid glands or ineffectiveness of increased secretion of parathyroid hormone.

We have investigated the prevalence of certain features of secondary hyperparathyroidism in a series of 21 untreated patients with osteomalacia, all shown by bone biopsy. Measurement of the renal clearance of phosphate was included to ascertain whether increased phosphaturia, being manifestation of hyperparathyroidism, is an invariable occurrence in osteomalacia, and whether such a measurement would be a useful clinical test for this disease.

\section{Patients Studied and Methods Used}

We report here all of our studies of patients with osteomalacia in whom we were able to complete the investigations, and in whom uraemia was not a factor (blood urea $<40$ mg. $/ 100 \mathrm{ml}$.), nor was there any other discernible cause for a raised serum alkaline phosphatase such as liver disease or Paget's disease, excepting one (Case 15) who had a tiny area of Paget's disease in the skull. The one essential selection criterion of these 21 patients was that the initial suspicion of osteomalacia was confirmed by iliac crest biopsy and qualitative examination of undecalcified sections stained by the method of von Kossa. Cases were included in this series only when at least two independent observers agreed that the osteoid clearly was abnormally excessive in thickness and extent. The identification of osteomalacia based simply on the quantity of osteoid will tend to underdiagnose the condition (Bordier et al., 1968). The causes of the osteomalacia were as follows: postgastrectomy 13 , idiopathic steatorrhoea 5 , and dietary deficiency 3.

Where possible the following metabolic examinations were made:

(1) Radiographs.-All patients had $x$-ray films of the hands and other bones from which could be ascertained the presence or absence of phalangeal erosions or pseudofractures; vertebral body collapse was sought as evidence of osteoporosis.

(2) (a) Serum calcium, phosphate, and serum alkaline phosphatase.-These were estimated in all patients on more than one occasion in the department of chemical pathology by standard methods (Wootton, 1964), and mean values are reported in the Table and subsequent figures. (b) Serum magnesium. This was measured (Wootton, 1964) in 12 of the patients. Only one (Case 11) had a subnormal value of $1.0 \mathrm{mEq} / 1$; (normal range 1.4-1.8 $\mathrm{mEq} / 1$.).

(3) 24-hour Strontium Space.-This measurement is a readily obtained index of the exchangeable calcium. A dose of $9.4 \mathrm{mEq}$ of stable strontium is given intravenously, and the strontium is mea- 
sured in the subsequent 24-hour urine and in the serum taken at 24 hours. The 24-hour space corrected for body weight is:

$\frac{9.4-\text { Urinary Sr (mEq) }}{\text { Serum Sr (mEq/1.) }} \times \frac{20}{\text { Body weight (kg.) }}=\operatorname{Sr}$ space (plasma units) Raised values ( $>18$ pl.u. are found in osteomalacia (Joplin et al., 1967), the measurement being possibly more sensitive to osteomalacia than even quantitative bone biopsy (Joplin et al., 1968). All the 20 patients of the present series in whom the strontium space was measured were found to have raised values (see Table), thus supporting the histological diagnosis of osteomalacia.

(4) Faecal Fat.-This was measured in two or more three-day pools in 15 of the patients, in the metabolic unit laboratory. Most results were corrected by chromium (Wootton, 1964). The mean fat excretions of the 15 patients in whom they were measured are quoted in the Table, nine patients showing steatorrhoea.

(5) Phosphate Excretion Index.-This was measured in all the patients. The test was performed as described by Nordin and Fraser (1960), after an overnight fast, the patients being on a low-calcium diet containing about $750 \mathrm{mg}$. of phosphorus. For each patient measurements on at least two mornings were made, from which mean values will be reported. This index takes into account the level of serum phosphate, so that the phosphate: creatinine clearance ratio is expressed as the departure from the value which would have been expected in a normal subject for the prevailing serum phosphate concentration.

\section{Results}

As can be seen from the Table summarizing the data of our 21 patients with osteomalacia, only eight had a raised value for the serum alkaline phosphatase, six of whom also showed subperiosteal bone resorption of the phalanges in the hand $x$-ray films. No erosions were found in 12 of the patients with a normal serum alkaline phosphatase; the one exception (Case 7) who had erosions had a marginal serum alkaline phosphatase of 12 K.A.u. There was thus a close correlation between the serum alkaline phosphatase level and the presence of erosions attributable to secondary hyperparathyroidism.

In seven of the eight patients with a raised serum alkaline phosphatase, the phosphate excretion index was also clearly raised. The one exception, Case 9, had a small alveolar erosion of unknown aetiology which might be the reason for the raised serum alkaline phosphatase of 18 K.A.u.; also in favour (see later) of the absence of secondary hyperparathyroidism in this particular woman is the low $(3.9 \mathrm{mEq} / 1$.) serum calcium. No raised values for the phosphate excretion index were found among the patients with a normal serum alkaline phosphatase. The correlation between the actual values of the phosphate excretion index and serum alkaline phosphatase for the whole series is shown in Fig. $1(\mathrm{r}=+0.84$; $\mathrm{P}<0.0001)$; also, the presence of erosions is shown to be virtually confined to the group with both a high serum alkaline phosphatase and a high phosphate excretion index.

When the serum calcium levels in this series are examined (Fig. 2) it is seen that all of the seven patients who had a raised phosphate excretion index had maintained their serum calcium within normal limits, whereas among those with a

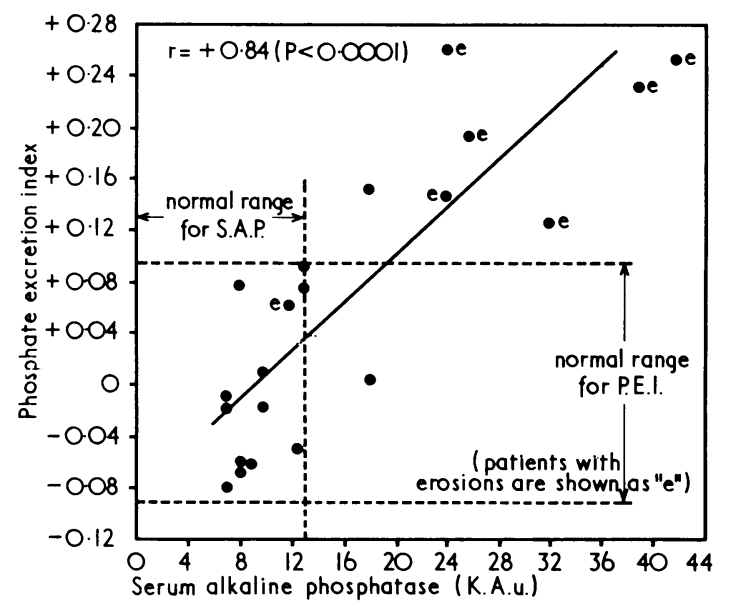

FIG. 1.-A close correlation between the phosphate excretion index and the levels of the serum alkaline phosphatase is seen (phosphate excretion index $=0.009 \times$ serum alkaline phosphatase-0.083). Erosions were almost entirely confined to those patients with both these biochemical indices of secondary hyperparathyroidism present.

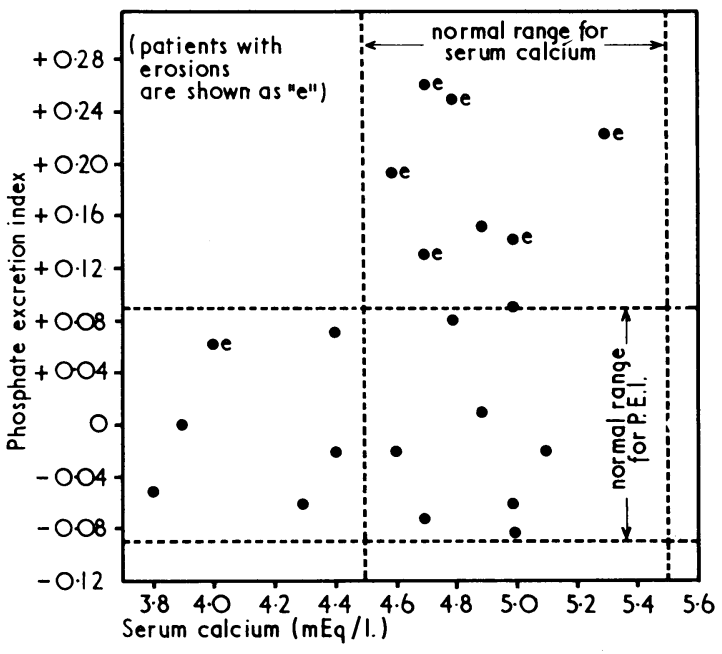

FIG. 2.-Those patients who failed to maintain a normal serum calcium also failed to show the raised phosphate excretion index of secondary hyperparathyroidism.

Biochemical and Radiological Findings in 21 Patients with Untreated Osteomalacia

\begin{tabular}{|c|c|c|c|c|c|c|c|c|c|c|c|c|}
\hline \multirow[b]{2}{*}{$\begin{array}{l}\text { Case } \\
\text { No. }\end{array}$} & \multirow[b]{2}{*}{$\begin{array}{l}\text { Age } \\
\text { and } \\
\text { Sex }\end{array}$} & \multicolumn{3}{|c|}{$X$-Ray Findings } & \multicolumn{4}{|c|}{ Serum } & \multirow[b]{2}{*}{$\begin{array}{c}\text { P.E.I. } \\
\mathrm{N}= \pm 0.09\end{array}$} & \multirow[b]{2}{*}{$\begin{array}{c}\text { Sr Space } \\
(\text { pl.u.) } \\
N \geqq 18\end{array}$} & \multirow[b]{2}{*}{$\begin{array}{c}\text { Faecal Fat } \\
(\text { g/day }) \\
\mathrm{N} \geqq 5\end{array}$} & \multirow[b]{2}{*}{ Aetiology } \\
\hline & & Erosions & $\begin{array}{l}\text { Pseudo- } \\
\text { fractures }\end{array}$ & $\begin{array}{l}\text { Vertebral } \\
\text { Collapse }\end{array}$ & $\begin{array}{c}\text { Alkaline } \\
\text { Phosphatase } \\
\text { (K.A.u.) } \\
\mathbf{N} \geqq 13\end{array}$ & $\begin{array}{c}\mathrm{PO}_{4} \\
\mathrm{NEq} / 1 .) \\
\mathrm{N}=1 \cdot 4-2 \cdot 6\end{array}$ & $\begin{array}{c}\mathrm{Ca} \\
\mathrm{N}=4 \cdot 5-5.5\end{array}$ & $\begin{array}{c}\mathrm{Ca} \times \mathrm{P} \\
(\mathrm{mEq} / 1 .) \\
\mathrm{N}>\mathbf{8} \cdot 0\end{array}$ & & & & \\
\hline $\begin{array}{r}1 \\
2 \\
3 \\
4 \\
5 \\
6 \\
7 \\
8 \\
9 \\
10 \\
11 \\
12 \\
13 \\
14 \\
15 \\
16 \\
17 \\
18 \\
19 \\
20 \\
21\end{array}$ & $\begin{array}{l}69 \mathrm{~F} \\
70 \mathrm{~F} \\
76 \mathrm{~F} \\
73 \mathrm{~F} \\
72 \mathrm{~F} \\
48 \mathrm{~F} \\
70 \mathrm{~F} \\
69 \mathrm{~F} \\
83 \mathrm{~F} \\
85 \mathrm{~F} \\
35 \mathrm{~F} \\
72 \mathrm{~F} \\
47 \mathrm{M} \\
46 \mathrm{~F} \\
69 \mathrm{~F} \\
70 \mathrm{~F} \\
60 M \\
50 M \\
23 \mathrm{M} \\
55 \mathrm{M} \\
54 \mathrm{M}\end{array}$ & $\begin{array}{l}\text { Yes } \\
\text { Yes } \\
\text { Yes } \\
\text { Yes } \\
\text { Yes } \\
\text { Yes } \\
\text { Yes } \\
\text { No } \\
\text { No } \\
\text { No } \\
\text { No } \\
\text { No } \\
\text { No } \\
\text { No } \\
\text { No } \\
\text { No } \\
\text { No } \\
\text { No } \\
\text { No } \\
\text { No } \\
\text { No }\end{array}$ & $\begin{array}{l}\text { Yes } \\
\text { Yes } \\
\text { Yes } \\
\text { Yes } \\
\text { Yes } \\
\text { Yes } \\
\text { No } \\
\text { No } \\
\text { Yes } \\
\text { No } \\
\text { No } \\
\text { Yes } \\
\text { No } \\
\text { No } \\
\text { No } \\
\text { No } \\
\text { No } \\
\text { No } \\
\text { No } \\
\text { No } \\
\text { No }\end{array}$ & $\begin{array}{l}\text { No } \\
\text { Yes } \\
\text { No } \\
\text { Yes } \\
\text { Yes } \\
\text { No } \\
\text { Yes } \\
\text { No } \\
\text { Yes } \\
\text { No } \\
\text { No } \\
\text { Yes } \\
\text { No } \\
\text { No } \\
\text { Yes } \\
\text { Yes } \\
\text { No } \\
\text { No } \\
\text { No } \\
\text { No } \\
\text { No }\end{array}$ & $\begin{array}{r}42 \\
39 \\
32 \\
26 \\
24 \\
24 \\
12 \\
18 \\
18 \\
13 \\
13 \\
13 \\
10 \\
10 \\
9 \\
8 \\
8 \\
8 \\
7 \\
7 \\
7\end{array}$ & $\begin{array}{l}1 \cdot 7 \\
1.4 \\
1.9 \\
1.5 \\
2.1 \\
1.6 \\
1.4 \\
2.0 \\
1.9 \\
1.7 \\
1.6 \\
1.5 \\
2 \cdot 0 \\
2 \cdot 2 \\
2.1 \\
2.0 \\
2 \cdot 1 \\
1.6 \\
2.0 \\
1.7 \\
2.4\end{array}$ & $\begin{array}{l}4 \cdot 8 \\
5 \cdot 3 \\
4 \cdot 7 \\
4 \cdot 6 \\
5 \cdot 0 \\
4 \cdot 7 \\
4 \cdot 0 \\
4 \cdot 9 \\
3 \cdot 9 \\
5 \cdot 0 \\
3 \cdot 8 \\
4 \cdot 4 \\
4 \cdot 9 \\
4 \cdot 6 \\
4 \cdot 3 \\
4 \cdot 8 \\
5 \cdot 0 \\
4 \cdot 7 \\
4 \cdot 4 \\
5 \cdot 1 \\
5 \cdot 0\end{array}$ & $\begin{array}{r}8 \cdot 2 \\
7.4 \\
8 \cdot 9 \\
6 \cdot 9 \\
10 \cdot 5 \\
7 \cdot 5 \\
5 \cdot 6 \\
9 \cdot 8 \\
9 \cdot 8 \\
8 \cdot 5 \\
6 \cdot 1 \\
6 \cdot 6 \\
9 \cdot 8 \\
10 \cdot 1 \\
9 \cdot 0 \\
9 \cdot 6 \\
10.5 \\
7.5 \\
8 \cdot 8 \\
8 \cdot 7 \\
12.0\end{array}$ & $\begin{array}{r}+.25 \\
+.23 \\
+.13 \\
+.19 \\
+.14 \\
+.26 \\
+.06 \\
+.15 \\
0 \\
+.09 \\
-.05 \\
+.07 \\
+.01 \\
-.02 \\
.06 \\
+.08 \\
-.06 \\
-.07 \\
=.02 \\
=.02 \\
-.08\end{array}$ & $\begin{array}{l}40 \\
34 \\
32 \\
30 \\
37 \\
23 \\
26 \\
26 \\
37 \\
22 \\
32 \\
35 \\
21 \\
20^{*} \\
20 \\
25 * \\
21 \\
23 \\
20^{*} \\
19\end{array}$ & $\begin{array}{r}3 \\
8 \\
10 \\
3 \\
29 \\
4 \\
24 \\
8 \\
5 \\
1 \\
17 \\
7 \\
11 \\
8 \\
4\end{array}$ & $\begin{array}{l}\text { Postgastrectomy } \\
\text { ", } \\
\text { ”, } \\
\text { Dietary " } \\
\text { Idiopathic steatorrhoea } \\
\text { Postgastrectomy } \\
\text { Idiopathic steatorrhoea } \\
\text { Dietary } \\
\text { Idiopathic steatorrhoea } \\
\text { Postgastrectomy" } \\
\text { ?Dietary } \\
\text { Postgastrectomy } \\
\text { ", } \\
\text { Idiopathic steatorrhoea } \\
\text { Postgastrectomy }\end{array}$ \\
\hline
\end{tabular}


normal phosphate excretion index, six had a clearly subnormal serum calcium, The validity of the low serum calcium (representing the mean of at least three separate estimations) was substantiated by the finding of normal serum proteins in the six hypocalcaemic patients.

The mean serum magnesium in the five hypocalcaemic patients in whom it was estimated was $1.6 \mathrm{mEq} / 1$., whereas in the seven normocalcaemic patients the mean value was 1.7 $\mathrm{mEq} / 1$.; thus there is no real difference between the two mean values.

When the classical criteria of osteomalacia are examined in the Table, it is seen that subnormal values were found for the serum calcium in six patients, for the phosphate in none (four were borderline and 16 were in the lower half of the normal range), and for the calcium $\times$ phosphate product in seven; the serum alkaline phosphatase was raised in eight patients. Erosions or pseudofractures were present in nine. We are left with seven patients who did not show any of those classical biochemical or radiological abnormalities characterising osteomalacia. All 20 patients in whom the strontium space was estimated, however, had abnormal bone avidity for strontium, thus supporting the histological diagnosis of osteomalacia; furthermore, the values were proportional to the serum alkaline phosphatase, as is seen in Fig. $3(\mathrm{r}=+0.72 ; \mathrm{P}<0.001)$.

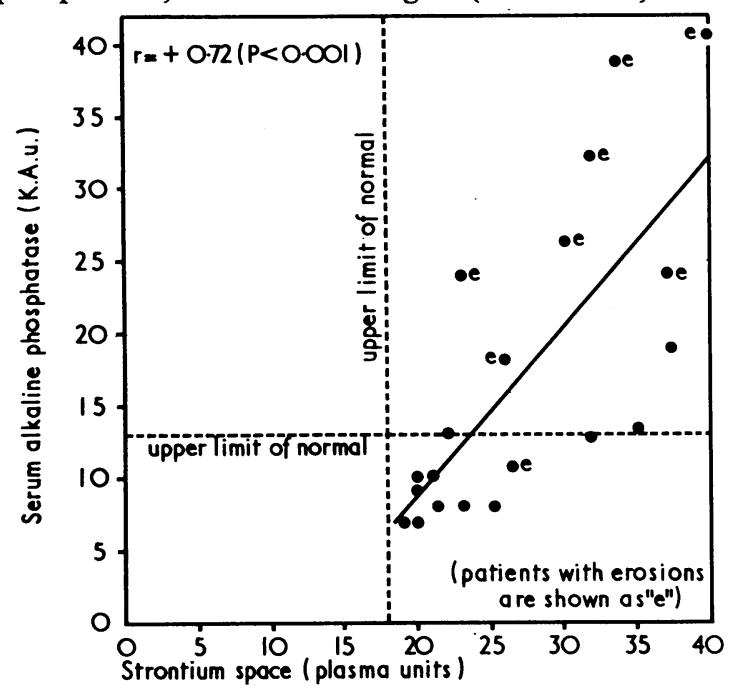

FIG. 3.-A close correlation between the serum alkaline phosphatase and 24-hour strontium space is seen (serum alkaline phosphatase $=1.14 \times \mathrm{Sr}$ space-13:9).

In view of the importance of confirming the diagnosis of osteomalacia in the cases with normal biochemistry and radiology a second space measurement was made after treatment in three (Cases 14, 16 and 20); all now had normal values; in a fourth case (No. 13) there was also an abnormal calcium infusion test before treatment (Nordin and Fraser, 1956).

\section{Discussion}

In this series of patients with histologically shown osteomalacia, we have a group of five with a low serum calcium level yet lacking any biochemical (phosphate excretion index or serum alkaline phosphatase) evidence of secondary hyperparathyroidism. Indeed the phosphate excretion index was related to the serum calcium level (Fig. 2) and was also directly proportional to the serum alkaline phosphatase level (Fig. 1). The latter is generally considered to reflect the severity of parathyroid overactivity (Arnstein et al., 1967) and in turn was found to be proportional to bone avidity for strontium (Fig. 3). We are not aware of this curious failure of development of secondary hyperparathyroidism having been shown biochemically before in patients with histologically evident osteomalacia and hypocalcaemia, though the lack of radiological signs in a proportion of hypocalcaemic patients with or without other biochemical features of osteomalacia due to presumed vitamin-D deficiency is well recognized (Salvesen and Böe, 1953; Fourman and Haapanen, 1964; Fraser et al., 1967); some such patients have even presented with frank tetany. It is not uncommon to find a normal serum alkaline phosphatase, calcium, or phosphate level in histologically evident osteomalacia even when examined quantitatively (Arnstein et al., 1967; Joplin et al., 1968).

A number of theories have been put forward to explain this failure of secondary hyperparathyroidism to develop.

Salvesen and Böe (1953) raised the possibility of malabsorption of a lipid that is vital for parathyroid activity; they likened it, as also did Nordin (1961), to the adrenal insufficiency found in some patients with steatorrhoea-for example, Mickerson (1960).

Fourman and Haapanen (1964) listed as possibilities (1) exhaustion of the parathyroids simulating hypoparathyroidism, (2) failure of the bone to respond to parathyroid hormone due to deficiency of vitamin $\mathrm{D}$, and (3) alteration of the sensitivity of the parathyroids to hypocalcaemia, the glands responding only to much lower serum calcium levels than they do normally. They concluded from their own data that hypocalcaemia in patients with osteomalacia and steatorrhoea is caused by a block in the action of parathyroid hormone that is unrelated to vitamin $\mathrm{D}$. Their administered parathyroid extract failed to increase phosphate excretion, though from their data it is not certain that this preparation had a definite effect in normal subjects. Evanson (1966) also gave infusions of parathyroid extract to hypocalcaemic patients with steatorrhoea, and found no effect on the serum calcium: he concluded that on the available evidence it seemed unlikely that the relative osseous unresponsiveness of these patients to parathyroid hormone was accompanied by reduced renal tubular sensitivity.

The fact that one of our patients (Case 15) with hypocalcaemic osteomalacia and normal phosphate excretion index did not have steatorrhoea at all, and that the early stage of vitamin-D deficiency rickets of ten has a low serum calcium without hyperphosphaturia (Fraser et al., 1967) would seem to make it unlikely that it is malabsorption of a lipid substance that leads to failure of parathyroid hormone effect.

Finally, hypomagnesaemia has been shown to be a cause of refractoriness of bone and kidney to parathyroid extract (Estep et al., 1969). This was unlikely to be the explanation in our study, because of five patients with a low serum calcium in whom serum magnesium was estimated, four had normal values; furthermore, there was no difference in mean serum magnesium in the hypocalcaemic and normocalcaemic groups.

The urinary excretion of phosphate in subjects on a standard intake of calcium and phosphate, though dependent on a number of factors, including the glomerular filtration rate (Goldman and Bassett, 1954; de Wardener, 1967), the presence or absence of acidosis (Milne et al., 1952), the prevailing serum phosphate concentration (Milne et al., 1952), and possibly thyrocalcitonin (Singer et al., 1969), is mainly dependent on parathyroid activity (Hiatt and Thompson, 1957; Gershberg et al., 1959; Beutner and Munson, 1960; Arnaud et al., 1967). This phosphaturic action of parathyroid hormone is not dependent on the presence of vitamin $\mathrm{D}$ whereas the action to mobilize bone mineral is (Rasmussen et al., 1963; DeLuca, 1967).

Our finding of a normal phosphate excretion index in some patients with hypocalcaemic osteomalacia would therefore suggest a mechanism involving the failure of an increase in the release of parathyroid hormone. In accordance with this mechanism are the findings of Taitz and de Lacy (1962) in infants with rickets; out of 36 such children the group with the lowest serum calcium had also the lowest phosphate excretion index and the highest serum phosphate; furthermore, administration of parathyroid extract did result in a rise in the 
serum calcium and a drop in the serum phosphate. Unfortunately it was not stated whether there was radiological evidence of secondary hyperparathyroidism.

The feature that emerges from the present study is that augmented phosphaturia is by no means a constant finding in osteomalacia. Thus this measurement is not a useful clinical test for the presence of osteomalacia. It is, however, of conceptual interest to find that this is so, as it points to failure of an increase in parathyroid hormone secretion as a likely cause of the well-documented occurrence of osteomalacia without overt evidence of secondary hyperparathyroidism. The cause of such failure is not shown from the present study. Possibly this failure is relatively common in that a proportion of patients with renal failure also fail to manifest secondary hyperparathyroidism (Stanbury and Lumb, 1966), though the mechanisms involved might be different. Direct assay of serum parathyroid hormone is required to pursue this question further. In addition, it is confirmed from our series that the 24-hour strontium space is a sensitive practical test for screening for osteomalacia in that it was the only measurement that was found to be abnormal in every patient.

We are grateful to the department of chemical pathology for some of the serum estimations, to the department of morbid anatomy for their reports on the bone biopsies, to the staff of the metabolic unit, and to Miss Rita Hessey for assistance with the statistical calculations. Sandoz Ltd. (Dr. D. S. Freestone) generously supplied the strontium. We would also like to express our thanks to Professor Russell Fraser for his helpful criticism of the manuscript. N.C.T. gratefully acknowledges a W.H.O. Fellowship.

REFERENCES

Albright, F., and Reifenstein, E. C. (1948). The Parathyroid Glands and Metabolic Bone Disease, p. 216. Baltimore, Williams \& Wilkins.
Arnaud, C. D., jun., Tenenhouse, A. M., and Rasmussen, H. (1967). Annual Review of Physiology, 29, 349.

Arnstein, A. R., Frame, B., and Frost, H. M. (1967). Annals of Internal Medicine, 67, 1296.

Au, W. Y. W., and Raisz, L. G. (1965). American fournal of Physiology, 209, 637.

Bartos, H. R., and Henneman, P. H. (1965). Fournal of Clinical Endocrinology and Metabolism, 25, 1522 .

Beutner, E. H., and Munson, L. P. (1960). Endocrinology, 66, 610.

Bordier, P., et al. (1968). Lancet, 1, 437.

DeLuca, H. F. (1967). Vitamins and Hormones, 25, 315

de Wardener, H. E. (1967). The Kidney, 3rd ed., p. 75 . London, Churchill. Estep, H., et al. (1969). Fournal of Clinical Endocrinology and Metabolism, 29,842 .

Evanson, J. M. (1966). Clinical Science, 31, 63.

Fourman, P., and Haapanen, E. (1964). Schweizerische medizinische Wochenschrift, 94, 886.

Fourman, P., and Royer, P. (1968). Calcium Metabolism and the Bone, 2nd. ed., p. 285. Oxford, Blackwell.

Fraser, D., Kooh, S. W., and Scriver, C. R. (1967). Pediatric Research, 1, 425

Gershberg, H., Shields, D. R., and Kove, S. A. (1959). Fournal of Clinical Endocrinology and Metabolism, 19, 681 .

Goldman, R., and Bassett, S. H. (1954). Fournal of Clinical Investigation, 33, 1623 .

Hiatt, H. H., and Thompson, D. D. (1957). Fournal of Clinical Investigation, 36, 557.

Joplin, G. F., Robinson, C. J., Melvin, K. E. W., Thompson, G. R., and Fraser, R. (1967). In l'Osteomalacie, edited by D. J. Hioco, p. 249. Paris, Masson.

Joplin, G. F., Melvin, K. E. W., Hepner, G. W., Neale, G., and Bordier, P. (1968). Calcified Tissue Research, 2, Suppl., 63.

Mickerson, J. N. (1960). British Medical fournal, 1, 529.

Milne, M. D., Stanbury, S. W., and Thomson, A. E. (1952). Quarterly fournal of Medicine, $21,61$.

Nordin, B. E. C. (1961). Proceedings of the Royal Society of Medicine, 54, 497. Nordin, B. E. C., and Fraser, R. (1960). Lancet, 1, 947.

Rasmussen, H., DeLuca, H., Arnaud, C., Hawker, C., and Von Stedingk, M. (1963). Yournal of Clinical Investigation, 42, 1940.

Salvesen, H. A., and Böe, J. (1953). Acta Medica Scandinavica, 146, 290 Singer, F. R., Woodhouse, N. J. Y., Parkinson, D. K., and Joplin, G. F (1969). Clinical Science, 37, i81.

Stanbury, S. W., and Lumb, G. A. (1966). Quarterly fournal of Medicine, $35,1$.

Taitz, L. S., and de Lacy, C. D. (1962). Pediatrics, 30, 884.

Wootton, I. D. P. (1964). Micro-analysis in Medical Biochemistry, 4th ed. London, Churchill.

\title{
Alterations in Lumbar Cerebrospinal Fluid Protein During Air Encephalography
}

\author{
J. RANALD W. DYKES, ${ }^{*}$ M.B., CH.B., B.SC. ; DAVID L. STEVENS, $†$ M.B., M.R.C.P.
}

Cummary: A significant fall occurred in the protein content of successive specimens of lumbar cerebrospinal fluid (C.S.F.) withdrawn during the course of air encephalography in $57 \%$ of cases. No correlation was found between the fall in the protein concentration and the total volume of air injected or the total volume of C.S.F. withdrawn, but the size of the fall was greater when the initial lumbar C.S.F. protein concentration was raised. The importance of taking specimens for routine laboratory analysis before the injection of any air is emphasized.

\section{Introduction}

In the investigation of neurological disease, protein concentration is often determined in cerebrospinal fluid (C.S.F.) removed at lumbar puncture and then later in a specimen withdrawn during air encephalography. Under these circumstances it is often noted that the concentrations are different and occasionally widely so. This discrepancy can be particularly confusing if one of the two readings is within the normal range and the other is outside it. The present investigation has been carried out in an attempt to clarify this situation.

* Lecturer in Chemical Pathology, School of Medicine, Leeds.

† Senior Registrar in Neurology, the General Infirmary at Leeds.
Since Dandy (1919) introduced the technique of air encephalography there have been many reports on the changes in the cellular content of the C.S.F. during and after the procedure (Aird, 1936; Lund and Neel, 1941; Frick, 1956; Roskamp, 1961), but few reports have dealt with the changes in the protein concentration, although it has been known for many years that the protein content of the ventricular C.S.F. is lower than that in the cisterna magna and the lumbar theca (Lups and Haan, 1954). Schwab and von Storch (1937) investigated the protein concentration of lumbar C.S.F. withdrawn at 15-minute intervals during the hour taken to perform air encephalography in 59 patients. They found a decrease in the protein content during the replacement of C.S.F. by air, followed by a return to the original value by the end of the procedure. Bickerstaff $(1950,1951)$ determined the protein concentration in the initial and final lumbar C.S.F. specimens in 57 patients and found a fall in 24 , no change in 23 , and a rise in the remaining 10. Marrack et al. (1961) measured the protein content before and after air encephalography in 81 patients. In 78 they noted a drop, which averaged $11 \mathrm{mg} . / 100$ $\mathrm{ml}$.

In this paper the drop in protein content has been examined with particular reference to the volume of air injected, the volume of C.S.F. withdrawn, and the initial lumbar fluid protein concentration. Because of previous comprehensive 